\title{
Assessment of the antiproliferative and antigenotoxic activity and phytochemical screening of aqueous extracts of Sambucus australis Cham. \& Schltdl. (ADOXACEAE)
}

\author{
MARÍLIA TEDESCO ${ }^{1}$, ANDRIELLE W. KUHN', VIVIANE DAL-SOUTO FRESCURA ${ }^{2}$, ALINE A. \\ BOLIGON $^{3}$, MARGARETH L. ATHAYDE ${ }^{*}$, SOLANGE B. TEDESCO ${ }^{4}$ and ANTONIO C.F. DA SILVA ${ }^{4}$ \\ ${ }^{1}$ Programa de Pós-Graduação em Fitotecnia, Faculdade de Agronomia, Departamento de Horticultura e Silvicultura, \\ Universidade Federal do Rio Grande do Sul, Av. Bento Gonçalves, 7712, 91540-000 Porto Alegre, RS, Brazil \\ ${ }^{2}$ Coordenação Acadêmica, Universidade Federal de Santa Maria, Campus Cachoeira do Sul, Av. \\ Presidente Vargas, 1958, Santo Antônio, 96506-322 Cachoeira do Sul, RS, Brazil \\ ${ }^{3}$ Programa de Pós-Graduação em Ciências Farmacêuticas, Centro de Ciências da Saúde, Universidade \\ Federal de Santa Maria, Av. Roraima, 1000, 97105-900 Santa Maria, RS, Brazil \\ ${ }^{4}$ Departamento de Biologia, Centro de Ciências Naturais e Exatas, Universidade Federal \\ de Santa Maria, Av. Roraima, 1000, 97105-900 Santa Maria, RS, Brazil
}

Manuscript received on February 25, 2015; accepted for publication on July 5, 2016

\begin{abstract}
The purpose of this study was to evaluate the antiproliferative and antigenotoxic activity of Sambucus australis Cham. \& Schltdl. aqueous extracts on the cell cycle of Allium cepa L. as well as determine the phenolic compounds in such extracts. $S$. australis inflorescences and leaves of two accessions were used for aqueous extract preparation at concentrations: $0.003 \mathrm{~g} / \mathrm{ml}$ and $0.012 \mathrm{~g} / \mathrm{ml}$. A. cepa bulbs were rooted in distilled water and, subsequently, placed in treatments for 24 hours. Rootlets were collected and fixed in modified Carnoy's solution for 24 hours and kept. The squash technique was performed for slide preparation. Root tips were smashed and stained with $2 \%$ acetic orcein, and a total of 4000 cells per treatment were analyzed. The phenolic compounds were determined using high-performance liquid chromatography and data was analyzed using the Scott-Knott test. The results show that S. australis aqueous extracts have antiproliferative potential. Besides, the extracts prepared from $S$. australis leaves of both accessions at a concentration of $0.012 \mathrm{~g} / \mathrm{ml}$ have shown antigenotoxic activity. The phytochemical analysis allowed us to determine the presence of flavonoids and phenolic acids, of which kaempferol and chrologenic acid were the most predominant compounds in the extracts from the inflorescences and leaves, respectively.
\end{abstract}

Key words: medicinal plants, mitotic index, Allium cepa, sabugueiro, high-performance liquid chromatography.

Correspondence to: Marília Tedesco

E-mail: marilia_tedesco@hotmail.com

*in memoriam 


\section{INTRODUCTION}

According to ancient civilizations records, the use of medicinal plants to either soften symptoms or fight diseases dates back to five thousand years ago. Presently, they are still the only source of medicine for many people in various parts of the world (Hamburger and Hostettmann 1991). In Brazil, this practice had its origins with indigenous communities and, combined with other practices brought by African slaves and Portuguese settlers, resulted in a rich popular culture (MJC Nogueira, unpublished data).

Among the medicinal plants with high healing potential, it is found the Sambucus australis Cham. \& Schltdl. - a plant belonging to the family Adoxaceae that is popularly known in Brazil as sabugueiro. The Sambucus australis is a small tree or shrub that reaches 3-4 meters of height with irregular crown, twisted trunk and a fissured bark. It has pinnately compound leaves with leaflets membranous, and small, white and odoriferous flowers in terminal corymbs (Lorenzi and Matos 2008). The Sambucus australis is a Brazilian native species found in the southeast and south of Brazil until the state of Rio Grande do Sul; and it is found in Paraguay, Argentina and Uruguay (Bacigalupo 1974, Reitz 1985) as well. In the form of a dye, this plant is used as diaphoretic, carminative and diuretics. Infusions prepared from its barks and leaves are prescribed to treat inflammation, rheumatism, burn and pain (Jorge et al. 1999, Guarrera et al. 2005). Its flowers, in the form of infusion; besides being recommend to soften the symptoms of measles and chicken pox, work as diuretics, antipyretic, antiinflammatory, mild laxative and for the treatment of respiratory diseases. (Cruz 1979, Reitz 1985, Lorenzi and Matos 2008).

Despite being extensively used, the majority of the medicinal plants has not been widely investigated, mainly regarding their genotoxic potential. Besides, recent studies have shown that plant extracts have great potential as medicines to prevent or soften damages caused to the human body (Cordell 1995). Thus, the evaluation of the genotoxic and antigenotoxic potential of medicinal plants, performed through the Allium cepa test, is important for the population to make a safer use of such plants (Sturbelle et al. 2010).

The Allium cepa test is considered an efficient essay for the analysis and in situ monitoring of the genotoxicity of environmental substances, and it is validated by the International Program on Chemical Safety (IPCS, OMS) and the United Nations Environment Program (UNEP) (Silva et al. 2004). It is a fast and low-cost method that makes it possible to evaluate chromosomal damage and mitotic cycle perturbations, because the onion shows large chromosomes in reduced number $(2 \mathrm{n}=16)$ (Fiskesjö 1985) and it is highly sensitive to clastogenic agents (Leme and MarinMorales 2008). Moreover, the Allium cepa test has been corroborated by several researchers who carried it out together with in vitro testing using rat bone marrow cells and/or human lymphocytes obtaining similar results (Camparoto et al. 2002, Teixeira et al. 2003, Pinho et al. 2010). A study on the cytogenetic effect of Arum maculatum extract on the bone marrow cells of mice, conducted by Modallal et al. (2008), found similar results to those obtained by Kabarity and Malallah (1980) with khat extract who used Allium cepa root tips.

The genotoxic effects caused by plant species are mainly due to the mutagenic agents in their composition or their own secondary metabolism (Bagatini et al. 2007). According to Kutchan (2001), the synthesis of secondary metabolites is influenced by the environmental conditions, since they represent a chemical interface between plants and the surrounding environment. The main factors that can coordinate or alter the production of secondary metabolites are the season, temperature, water resources, pluviometric index, altitude and 
the genetic variability (Gobbo-Neto and Lopes 2007, Frescura et al. 2012).

Phenolic compounds consist of a rather representative class of secondary metabolites in abundance in the plant kingdom. They form a chemically heterogeneous group with approximately ten thousand compounds, of which two large groups are known in nature, namely phenolic acids and flavonoids (Taiz and Zeiger 2013). The use of chromatographic profiles or fingerprinting for the analysis of plant extracts makes it possible to observe a great number of chemical compounds in a given sample thus providing a standard to compare similarities and differences among extracts submitted to the same analytical circumstances (Alaerts et al. 2007).

This study aimed to evaluate the antiproliferative, genotoxic and antigenotoxic activity in aqueous extracts from Sambucus australis leaves and inflorescences of two accessions using the Allium cepa test system, as well as to determine the phenolic compounds in such extracts using the high-performance liquid chromatography (HPLCDAD).

\section{MATERIALS AND METHODS}

\section{PLANT MATERIAL SAMPLING}

Inflorescences and leaves of two Sambucus australis accessions were collected in the spring, in September 2013, in the cities of Santa Maria, Rio Grande do Sul, Brazil (Accession 1: 2940’41.2”S and 53 47'21.6” W) and Erechim, Rio Grande do Sul, Brazil (Accession 2: 27 $7^{\circ} 3^{\prime} 13^{\prime \prime} \mathrm{S}$ and $52^{\circ} 18^{\prime} 43^{\prime \prime}$ ). According to Köppen classification (1948), the climate in this region is Cfa (humid subtropical, with hot summers and an average temperature of the warmest month above $22^{\circ} \mathrm{C}$ ). The choice for these two cities was based on a great difference of altitude $(113 \mathrm{~m}$ and $783 \mathrm{~m}$, respectively). The inflorescences and leaves were stored at room temperature $\left(25^{\circ} \mathrm{C}\right)$ for 60 days and later it was performed the preparation of the aqueous extracts. The plant material from each accession was stored in the herbarium of the Department of Biology at the Federal University of Santa Maria (UFSM) under the following registration numbers: 15.421 (Accession 1) and 15.425 (Accession 2). The plants were identified by Thais do CantoDorow, $\mathrm{PhD}$, and the experiment was carried out at LABCITOGEN (Laboratory of Cytogenetics and Genotoxicity) at UFSM.

\section{EXTRACT PREPARATION}

In order to prepare the aqueous extracts, dried leaves and inflorescences of each accession were placed in a $1 \mathrm{~L}$ beaker containing boiling water at $100^{\circ} \mathrm{C}$, where they were allowed to steep for 10 minutes. Subsequently, the liquid was strained and cooled down until it reached room temperature. The aqueous extracts were prepared at two concentrations: $0.003 \mathrm{~g} / \mathrm{ml}$ (according to the National Health Surveillance Agency regulations for the species Sambucus (ANVISA 2010) and $0.012 \mathrm{~g} / \mathrm{ml}$ (four times more concentrated).

\section{In vivo Allium cepa TEST SYSTEM}

In order to verify the genotoxic and antigenotoxic activity in the Sambucus australis aqueous extracts, 15 groups with 4 Allium cepa bulbs were used in the experiment, each group corresponding to one treatment. These bulbs were placed in distilled water until their rootlets appeared. After the rootlets emerged, each group was transferred to their respective treatment. The first group (T1) remained only in distilled water and served as negative control while the remaining groups were transferred to the following treatments: T2: aqueous extract from inflorescences at $0.003 \mathrm{~g} / \mathrm{ml}$ (Accession 1 - Santa Maria); T3: aqueous extract from leaves at $0.003 \mathrm{~g} / \mathrm{ml}$ (Accession 1 - Santa Maria); T4: aqueous extract from inflorescences at $0.012 \mathrm{~g} / \mathrm{ml}$ (Accession 1 - Santa Maria); T5: aqueous extract 
from leaves at $0.012 \mathrm{~g} / \mathrm{ml}$ (Accession 1 - Santa Maria); T6: aqueous extract from inflorescences at $0.003 \mathrm{~g} / \mathrm{ml}$ (Accession 2 - Erechim); T7: aqueous extract from leaves at $0.003 \mathrm{~g} / \mathrm{ml}$ (Accession 2 Erechim); T8: aqueous extract from inflorescences at $0.012 \mathrm{~g} / \mathrm{ml}$ (Accession 2 - Erechim); T9: aqueous extract from leaves at $0.012 \mathrm{~g} / \mathrm{ml}$ (Accession $2-$ Erechim); T10: a 1\% glyphosate (positive control); T11: a 1\% glyphosate +24 hours in water; T12: a $1 \%$ glyphosate +24 hours in aqueous extract from inflorescences at $0.012 \mathrm{~g} / \mathrm{ml}$ (Accession 1 - Santa Maria); T13: a 1\% glyphosate +24 hours in aqueous extract from leaves at $0.012 \mathrm{~g} / \mathrm{ml}$ (Accession 1 - SM); T14: a 1\% glyphosate +24 hours in aqueous extract from inflorescences at $0.012 \mathrm{~g} / \mathrm{ml}$ (Accession 2 - Erechim); T15: a 1\% glyphosate + 24 hours in aqueous extract from leaves at $0.012 \mathrm{~g} /$ $\mathrm{ml}$ (Accession 2 - Erechim). After being 24 hours in the treatment solutions, the rootlets were collected, fixed in ethanol/acetic acid (3:1 v/v) for 24 hours and stored in $70 \%$ ethanol under refrigeration for subsequent slide preparation.

The glyphosate (a non-selective herbicide) was used as positive control because it has already proved to induce chromosomal alterations in Allium cepa meristematic cells (Souza et al. 2010, Frescura et al. 2012).

In order to verify any antigenotoxic activity, the groups of bulbs previously left in $1 \%$ glyphosate solution for 24 hours were placed in distilled water and in the Sambucus australis aqueous extracts at higher concentrations (T11, T12, T13, T14, T15) for more 24 hours with the purpose of observing the chromosomal damage caused by the glyphosate.

EFFECTS OF THE AQUEOUS EXTRACTS ON THE Allium cepa CELL CYCLE

The Allium cepa rootlets reaching approximately 2 $\mathrm{cm}$ were hydrolised in $\mathrm{HCl} 1 \mathrm{~N}$ for 5 minutes and washed in distilled water for slide preparation. The meristematic region of each rootlet was stained with $2 \%$ acetic-orcein, smashed with a glass rod and covered with a coverslip (Guerra and Souza 2002). Two slides per replicate (bulb) were prepared, 1000 cells per bulb were counted, summing up 4000 cells per treatment, reaching a total of 60000 cells. The slides were analyzed under a LEICA 400x magnification optical microscope. The Cells in the interphase and the cell division (mitosis) were observed to calculate the mitotic index as well as to identify chromosomal irregularities such as anaphase and telophase bridges, lost chromosomes, micronucleus and binucleated cells (Tedesco and Laughinghouse 2012). The mitotic index was calculated by dividing the number of cells undergoing mitosis by the total of cells observed, and the result was multiplied by 100 .

\section{HIGH-PERFORMANCE LIQUID CHROMATOGRAPHY (HPLC-DAD)}

The identification and quantification of the phenolic compounds in the aqueous extracts of Sambucus australis inflorescences and leaves was conducted by high-performance liquid chromatography. The analysis was carried out in the Laboratory of Phytochemistry of the Department of Industrial Pharmacy at the Federal University of Santa Maria.

\section{Chemical, apparatus and general procedures}

All chemical were of analytical grade. Acetonitrile, formic acid, gallic acid, caffeic acid, chlorogenic acid and ellagic acids purchased from Merck (Darmstadt, Germany). Quercetin, quercitrina, isoquercitrin, rutin and kaempferol were acquired from Sigma Chemical Co. (St. Louis, MO, USA). High performance liquid chromatography (HPLCDAD) was performed with a Shimadzu Prominence Auto Sampler (SIL-20A) HPLC system (Shimadzu, Kyoto, Japan), equipped with Shimadzu LC-20AT reciprocating pumps connected to a DGU 20A5 degasser with a CBM 20A integrator, SPD-M20A diode array detector and LC solution 1.22 SP1 software. 


\section{Quantification of compounds by HPLC-DAD}

Reverse phase chromatographic analyses were carried out under gradient conditions using $\mathrm{C}_{18}$ column $(4.6 \mathrm{~mm} \times 150 \mathrm{~mm})$ packed with $5 \mu \mathrm{m}$ diameter particles; the mobile phase was water containing 1\% formic acid (A) and acetonitrile (B), and the composition gradient was: $13 \%$ of $\mathrm{B}$ until $10 \mathrm{~min}$ and changed to obtain $20 \%, 30 \%, 50 \%$, $60 \%, 70 \%, 20 \%$ and $10 \%$ B at 20,30, 40, 50, 60, 70 and $80 \mathrm{~min}$, respectively, following the method described by Kamdem et al. (2013) with slight modifications. Sabugueiro leaves (Santa Maria and Erechim) and flowers (Santa Maria and Erechim) aqueous extracts and mobile phase were filtered through $0.45 \mu \mathrm{m}$ membrane filter (Millipore) and then degassed by ultrasonic bath prior to use, the extracts were analyzed at a concentration of 0.012 $\mathrm{g} / \mathrm{ml}$. The flow rate was $0.6 \mathrm{~mL} / \mathrm{min}$, injection volume $50 \mu \mathrm{l}$ and the wavelength were 254 for gallic acid, $325 \mathrm{~nm}$ for chlorogenic, caffeic and ellagic acids, and $365 \mathrm{~nm}$ for quercetin, quercitrin, isoquercitrin, kaempferol and rutin. All the samples and mobile phase were filtered through $0.45 \mu \mathrm{m}$ membrane filter (Millipore) and then degassed by ultrasonic bath prior to use. Stock solutions of standards references were prepared in the HPLC mobile phase at a concentration range of $0.025-$ $0.300 \mathrm{mg} / \mathrm{ml}$ for quercetin, quercitrin, isoquercitrin, rutin and kaempferol; and $0.050-0.450 \mathrm{mg} /$ $\mathrm{ml}$ for ellagic, gallic, caffeic and chlorogenic acids. Chromatography peaks were confirmed by comparing its retention time with those of reference standards and by DAD spectra (200 to $500 \mathrm{~nm}$ ). Calibration curve for gallic acid: $\mathrm{Y}=13174 \mathrm{x}+$ $1273.6(\mathrm{r}=0.9997)$; chlorogenic acid: $\mathrm{Y}=12764 \mathrm{x}$ $+1197.4(\mathrm{r}=0.9998)$; caffeic acid: $\mathrm{Y}=11992 \mathrm{x}$ $+1367.1(\mathrm{r}=0.9999)$; ellagic acid: $\mathrm{Y}=13286 \mathrm{x}$ $+1264.1(\mathrm{r}=0.9997)$; quercitrin: $\mathrm{Y}=12837 \mathrm{x}+$ 1364.5 ( $\mathrm{r}=0.9999)$; isoquercitrin: $\mathrm{Y}=12769 \mathrm{x}+$ 1326.5 ( $\mathrm{r}=0.9996)$; rutin: $\mathrm{Y}=13158 \mathrm{x}+1173.9$ $(\mathrm{r}=0.9998)$; quercetin: $\mathrm{Y}=13627 \mathrm{x}+1292.5(\mathrm{r}$
$=0.9996)$ and kaempferol: $\mathrm{Y}=13271 \mathrm{x}+1324.6$ $(\mathrm{r}=0.9999)$. All chromatography operations were carried out at ambient temperature and in triplicate.

The limit of detection (LOD) and limit of quantification (LOQ) were calculated based on the standard deviation of the responses and the slope using three independent analytical curves. LOD and LOQ were calculated as 3.3 and $10 \mathrm{\sigma} / \mathrm{S}$, respectively, where $\sigma$ is the standard deviation of the response and $\mathrm{S}$ is the slope of the calibration curve (Boligon et al. 2013).

\section{STATISTICAL ANALYSIS}

The data regarding the Allium cepa test as well as the high-performance liquid chromatography (HPLC-DAD) was submitted to analysis of variance and the means were compared using the Scott-Knott test (5\% error probability) using the ASSISTAT statistical software, version beta 7.7 (Silva and Azevedo 2009).

\section{RESULTS AND DISCUSSION}

In the present study, the effects of Sambucus australis aqueous extracts were evaluated using the Allium cepa test system. Table I shows the number of cells in the interphase, the number of cells undergoing division and the mitotic index of Allium cepa rootlets treated with the aqueous extracts, and the control groups prepared from the two Sambucus australis accessions. All the treatments differed statistically from the negative control (T1) causing a significant reduction in the mitotic index during the cell division.

The comparison of the mitotic index of the aqueous extracts prepared from Sambucus australis inflorescences of the two accessions at $0.003 \mathrm{~g} / \mathrm{ml}$ concentration showed that $\mathrm{T} 2$ (accession 1) had a significant difference from T6 (accession 2), and T6 caused a higher reduction in the mitotic index when compared to T2. Nevertheless, when the aqueous extracts prepared from Sambucus australis 
inflorescences of the two accessions at $0.012 \mathrm{~g} / \mathrm{ml}$ concentration were compared, the $\mathrm{T} 4$ (accession 1) did not have a significant difference from $T 8$ (accession 2). Similarly, the comparison of the mitotic index of the aqueous extracts prepared from Sambucus australis leaves of the two accessions at $0.003 \mathrm{~g} / \mathrm{ml}$ concentration showed that T3 (accession 1) significantly differed from $T 7$ (accession 2 ), the $\mathrm{T} 7$ caused a higher reduction in the mitotic index when compared to T3. On the other hand, when the aqueous extracts prepared from Sambucus australis leaves of the two accessions at $0.012 \mathrm{~g} /$ $\mathrm{ml}$ concentration were compared, T5 (accession 1) did not have a significant difference from $\mathrm{T} 9$ (accession 2).

By comparing the aqueous extracts from inflorescences of accession 1 at $0.003 \mathrm{~g} / \mathrm{ml}$ and $0.012 \mathrm{~g} / \mathrm{ml}, \mathrm{T} 2$ and T4 had a significant difference; the $\mathrm{T} 4$ caused a higher reduction in the mitotic index (MI). Similarly, when the aqueous extracts from leaves of this accession at the two concentrations were compared, T3 significantly differed from T5; the T5 caused a higher MI reduction. On the other hand, considering the aqueous extracts from inflorescences of the accession 2 at $0.003 \mathrm{~g} / \mathrm{ml}$ and $0.012 \mathrm{~g} / \mathrm{ml}$, T6 and T8 did not significantly differed. However, when the aqueous extracts from leaves of this accession at the two concentrations were compared, T7 and T9 showed a significant difference, T9 caused a higher MI reduction.

The results also show that the mitotic index in the negative control ( $\mathrm{MI}=7.85 \%)$ was significantly different from the mitotic index in the positive control $(\mathrm{MI}=5.17 \%)$. Besides, the analysis of the mitotic index among the treatments showed that T12 (1\% glyphosate +24 hours in aqueous extract of inflorescences at $0.012 \mathrm{~g} / \mathrm{ml}$ - Accession 1) was significantly different from T4 (aqueous extract of inflorescences at $0.012 \mathrm{~g} / \mathrm{ml}$-Accession 1) as well as from T2, T6, T7, T8, T9 and T13. The T13 (1\%

TABLE I

Number of cells in interphase and mitosis and the mitotic index of Allium cepa root tips for each treatment.

\begin{tabular}{|c|c|c|c|}
\hline Treatments & Cells in interphase & Cells in division & Mitotic index $(\%)$ \\
\hline T1: distilled water ${ }^{1}$ & 3686 & 314 & $7.85^{\mathrm{a}^{*}}$ \\
\hline $\mathrm{T} 2:$ inflorescences $0.003 \mathrm{~g} / \mathrm{ml}$ (accession 1) & 3903 & 97 & $2.42^{\mathrm{c}}$ \\
\hline T3: leaves $0.003 \mathrm{~g} / \mathrm{ml}$ (accession 1) & 3778 & 222 & $5.5^{\mathrm{b}}$ \\
\hline T4: inflorescences $0.012 \mathrm{~g} / \mathrm{ml}$ (accession 1) & 3970 & 30 & $0.75^{\mathrm{d}}$ \\
\hline T5: leaves $0.012 \mathrm{~g} / \mathrm{ml}$ (accession 1$)$ & 3968 & 32 & $0.8^{\mathrm{d}}$ \\
\hline T6: inflorescences $0.003 \mathrm{~g} / \mathrm{ml}$ (accession 2) & 3958 & 42 & $1.05^{\mathrm{d}}$ \\
\hline T7: leaves $0.003 \mathrm{~g} / \mathrm{ml}($ accession 2$)$ & 3926 & 74 & $1.85^{\mathrm{c}}$ \\
\hline T8: inflorescences $0.012 \mathrm{~g} / \mathrm{ml}$ (accession 2) & 3962 & 38 & $0.95^{\mathrm{d}}$ \\
\hline T9: leaves $0.012 \mathrm{~g} / \mathrm{ml}$ (accession 2) & 3961 & 39 & $0.97^{\mathrm{d}}$ \\
\hline T10: glyphosate $1 \%{\text { (glypho })^{2}}^{2}$ & 3793 & 207 & $5.17^{\mathrm{b}}$ \\
\hline T11: glypho $+24 \mathrm{~h}$ distilled water & 3828 & 172 & $4.3^{\mathrm{b}}$ \\
\hline T12: glypho $+24 \mathrm{~h}$ inflorescences $0.012 \mathrm{~g} / \mathrm{ml}($ accession 1$)$ & 3799 & 201 & $5.02^{\mathrm{b}}$ \\
\hline T13: glypho $+24 \mathrm{~h}$ leaves $0.012 \mathrm{~g} / \mathrm{ml}$ (accession 1$)$ & 3876 & 124 & $3.1^{\mathrm{c}}$ \\
\hline T14: glypho $+24 \mathrm{~h}$ inflorescences $0.012 \mathrm{~g} / \mathrm{ml}$ (accession 2$)$ & 3798 & 202 & $5.05^{\mathrm{b}}$ \\
\hline T15: glypho + leaves $0.012 \mathrm{~g} / \mathrm{ml}($ accession 2$)$ & 3809 & 191 & $4.77^{\mathrm{b}}$ \\
\hline $\mathrm{CV}(\%)^{3}$ & - & - & 30.36 \\
\hline
\end{tabular}

${ }^{1}$ Negative control; ${ }^{2}$ Positive control; ${ }^{3}$ Coefficient of variation; *Means with the same small letter in the column or capital letter on the line do not differ by the Scott-Knott test at $5 \%$ probability. 
glyphosate +24 hours in aqueous extract of leaves at $0.012 \mathrm{~g} / \mathrm{ml}$ - Accession 1) was significantly different from T5 (aqueous extract of leaves at $0.012 \mathrm{~g} / \mathrm{ml}$ - Accession 1) as well as from T3, T4, T6, T8, T9, T10, T11, T12, T14 and T15. The T14 ( $1 \%$ glyphosate +24 hours in aqueous extract of inflorescences at $0.012 \mathrm{~g} / \mathrm{ml}$ - Accession 2) was significantly different from T8 (aqueous extract of inflorescences at $0.012 \mathrm{~g} / \mathrm{ml}$ - Accession 2) as well as from T2, T4, T5, T6, T7, T9 and T13; and, the T15 ( $1 \%$ glyphosate +24 hours in aqueous extract of leaves at $0.012 \mathrm{~g} / \mathrm{ml}$-Accession 2) was significantly different from T9 (aqueous extract of leaves at $0.012 \mathrm{~g} / \mathrm{ml}-$ Accession 2) as well as from T2, T4, T5, T6, T7, T8 and T13.

The evaluation of the Sambucus australis aqueous extracts action using the Allium cepa test showed a significant inhibition of the cell division in all concentrations in both accessions, resulting in a reduction in the mitotic index, which indicates the antiproliferative activity of the aqueous extracts of this species. Besides, the mitotic index inhibition was higher in the extracts from the inflorescences and leaves at the higher concentration $(0.012 \mathrm{~g} /$ $\mathrm{ml})$ than in the extracts at the lower concentration $(0.003 \mathrm{~g} / \mathrm{ml})$ in both accessions.

Other authors also verified the antiproliferative activity in aqueous extracts from different species using the Allium cepa test system. In a study developed by Frescura et al. (2012), the authors studied the species Luehea divaricata Mart. and observed that the aqueous extracts from leaves (6 and $30 \mathrm{~g} / 1$ ) and barks of the stalk (32 and $160 \mathrm{~g} / 1)$ of two populations caused a reduction in the mitotic index in the cell cycle of Allium cepa. Moreover, this reduction accentuated as the extract concentrations increased, similarly to the results obtained with the Sambucus australis aqueous extracts in the present study. Knoll et al. (2006) reported the antiproliferative effect of the aqueous extracts from leaves of six populations of Pterocaulon polystachyum DC. at concentrations of $2.5 \mathrm{~g} / 1,5 \mathrm{~g} / 1$ and $10 \mathrm{~g} / 1$. Fachinetto et al. (2007) also studied the effect of aqueous extracts of Achyrocline satureioides DC. at concentrations of $5 \mathrm{~g} / 1$ and $20 \mathrm{~g} / 1$. In these studies, as in the present study, the aqueous extracts at higher concentrations presented a sharped inhibition of the mitotic index as compared to the extracts at lower concentrations and the negative control. The evaluation of the effect caused by infusions carried out with Solidago microglossa DC. leaves on the Allium cepa cell cycle, Bagatini et al. (2009) observed that the highest concentration tested $(14 \mathrm{mg} / \mathrm{ml})$ caused a reduction in the mitotic index, thus demonstrating the antiproliferative effect of this species.

According to Fachinetto et al. (2007), a high concentration of some compounds may cause inhibitory or stimulant effect upon the cell cycle. The aqueous extracts from leaves and inflorescences of Sambucus australis have flavonoids such as rutin, kaempferol, quercetin and quercitrin (Tables III and IV), which constitute an important class of phenolic compounds and are relatively abundant among plant secondary metabolites (Zuanazzi 2001). The antiproliferative activity of the aqueous extracts analyzed in this study may be assigned to the flavonoids found in the species Sambucus australis, since different pharmacologic effects, such as antiproliferative and anticarcinogenic action, are attributed to these compounds (Hollman et al. 1996, Pelzer et al. 1998). In a study developed by M. Scopel (unpublished data), the author also verified that the aqueous and hydroethanolic extracts of Sambucus australis flowers have a pronounced antioxidant effect, which may also explain the inhibition in the Allium cepa cell division caused by the aqueous extracts from leaves and inflorescences of Sambucus australis observed in the present study.

The cells of Allium cepa have eight pairs of relatively large chromosomes, allowing easy detection of possible chromosome damage. Furthermore, the chromosome morphology is 
easily altered by chemical and natural compounds (Firbas and Amon 2014). Table II shows the number of cells presenting chromosomal alterations and the types of alterations occurring in each treatment. The analysis, carried out through the Allium cepa test, of the cells in the interphase and the cell division showed chromosomal irregularities such as bridges in anaphase (Figure $1 \mathrm{a}$ and $1 \mathrm{~b}$ ) and telophase (Figure 1c), laggard chromosomes (Figure 1d), chromosomal breakage (Figure 1e) and micronucleus (Figure 1f). As Table II shows, there was a significant difference in terms of chromosomal alterations between the negative control (no alterations) and the positive control (50 alterations). The positive control (T10) also statistically differed from all the remaining treatments. However, the T2, T3, T4, T5, T6, T7, T8 and T9 did not have significant difference when compared to the negative control or among themselves. Regarding the numbers, the chromosomal alterations of these treatments were greatly reduced reaching the maximum of $0.05 \%$. For this reason, it was possible to verify that the aqueous extracts prepared from leaves and inflorescences of the two accessions of Sambucus australis did not present genotoxic effect upon Allium cepa meristematic cells. It is worth noting that, differently from our findings, some aqueous extracts of medicinal plants evinced genotoxic effect; for instance, the Baccharis trimera (Less.) DC. and Baccharis articulata (Lam.) Pers., Mikania glomerata Spreng., Mikania cordifolia (L. f.) Willd. and Eugenia uniflora L., investigated by Fachinetto and Tedesco (2009), Nora et al. (2010), Dias et al. (2014) and Kuhn et al. (2015), respectively.

The present study also aimed to assess the antigenotoxic effect of Sambucus australis aqueous extracts. In order to accomplish this purpose, the

TABLE II

Number, types and means of chromosomal abnormalities in Allium cepa root tips cells for each treatment.

\begin{tabular}{|c|c|c|c|c|}
\hline \multirow[b]{2}{*}{ Treatments } & \multicolumn{3}{|c|}{ Chromosomal abnormalities } & \multirow[b]{2}{*}{$\begin{array}{c}\text { Means } \\
\text { of alterations }\end{array}$} \\
\hline & $\mathrm{MN}^{\#}$ & $\begin{array}{c}\text { Anaphasic } \\
\text { and telophasic } \\
\text { bridges }\end{array}$ & $\begin{array}{c}\text { Laggard } \\
\text { chromossome/ } \\
\text { breakages }\end{array}$ & \\
\hline T1: distilled water ${ }^{1}$ & - & - & - & $0^{\mathrm{d}^{*}}$ \\
\hline $\mathrm{T} 2$ : inflorescences $0.003 \mathrm{~g} / \mathrm{ml}$ (accession 1$)$ & - & 1 & 1 & $0.5^{\mathrm{d}}$ \\
\hline T3: leaves $0.003 \mathrm{~g} / \mathrm{ml}($ accession 1$)$ & - & - & - & $0^{\mathrm{d}}$ \\
\hline T4: inflorescences $0.012 \mathrm{~g} / \mathrm{ml}$ (accession 1) & - & - & - & $0^{\mathrm{d}}$ \\
\hline T5: leaves $0.012 \mathrm{~g} / \mathrm{ml}$ (accession 1$)$ & - & - & - & $0^{\mathrm{d}}$ \\
\hline T6: inflorescences $0.003 \mathrm{~g} / \mathrm{ml}$ (accession 2) & - & - & - & $0^{\mathrm{d}}$ \\
\hline T7: leaves $0.003 \mathrm{~g} / \mathrm{ml}($ accession 2$)$ & - & - & - & $0^{\mathrm{d}}$ \\
\hline T8: inflorescences $0.012 \mathrm{~g} / \mathrm{ml}$ (accession 2) & - & - & 1 & $0.25^{\mathrm{d}}$ \\
\hline T9: leaves $0.012 \mathrm{~g} / \mathrm{ml}($ accession 2$)$ & - & 2 & - & $0.5^{\mathrm{d}}$ \\
\hline T10: glyphosate $1 \%(\text { glypho })^{2}$ & - & 37 & 13 & $12.5^{\mathrm{a}}$ \\
\hline T11: glypho $+24 \mathrm{~h}$ distilled water & - & 16 & 1 & $4.25^{\mathrm{b}}$ \\
\hline T12: glypho $+24 \mathrm{~h}$ inflor. $0.012 \mathrm{~g} / \mathrm{ml}$ (accession 1$)$ & 2 & 23 & 2 & $6.75^{\mathrm{b}}$ \\
\hline T13: glypho $+24 \mathrm{~h}$ leaves $0.012 \mathrm{~g} / \mathrm{ml}($ accession 1$)$ & 1 & 8 & 2 & $2.7^{\mathrm{c}}$ \\
\hline T14: glypho $+24 \mathrm{~h}$ inflor. $0.012 \mathrm{~g} / \mathrm{ml}($ accession 2$)$ & - & 12 & 9 & $5.2^{\mathrm{b}}$ \\
\hline T15: glypho + leaves $0.012 \mathrm{~g} / \mathrm{ml}$ (accession 2) & - & 9 & 1 & $2.5^{\mathrm{c}}$ \\
\hline $\mathrm{CV}(\%)^{3}$ & - & - & - & 67.06 \\
\hline
\end{tabular}

${ }^{1}$ Negative control; ${ }^{2}$ Positive control; ${ }^{3}$ Coefficient of variation; *Means with the same small letter in the column or capital letter on the line do not differ by the Scott-Knott test at 5\% probability. \#Micronucleus. 

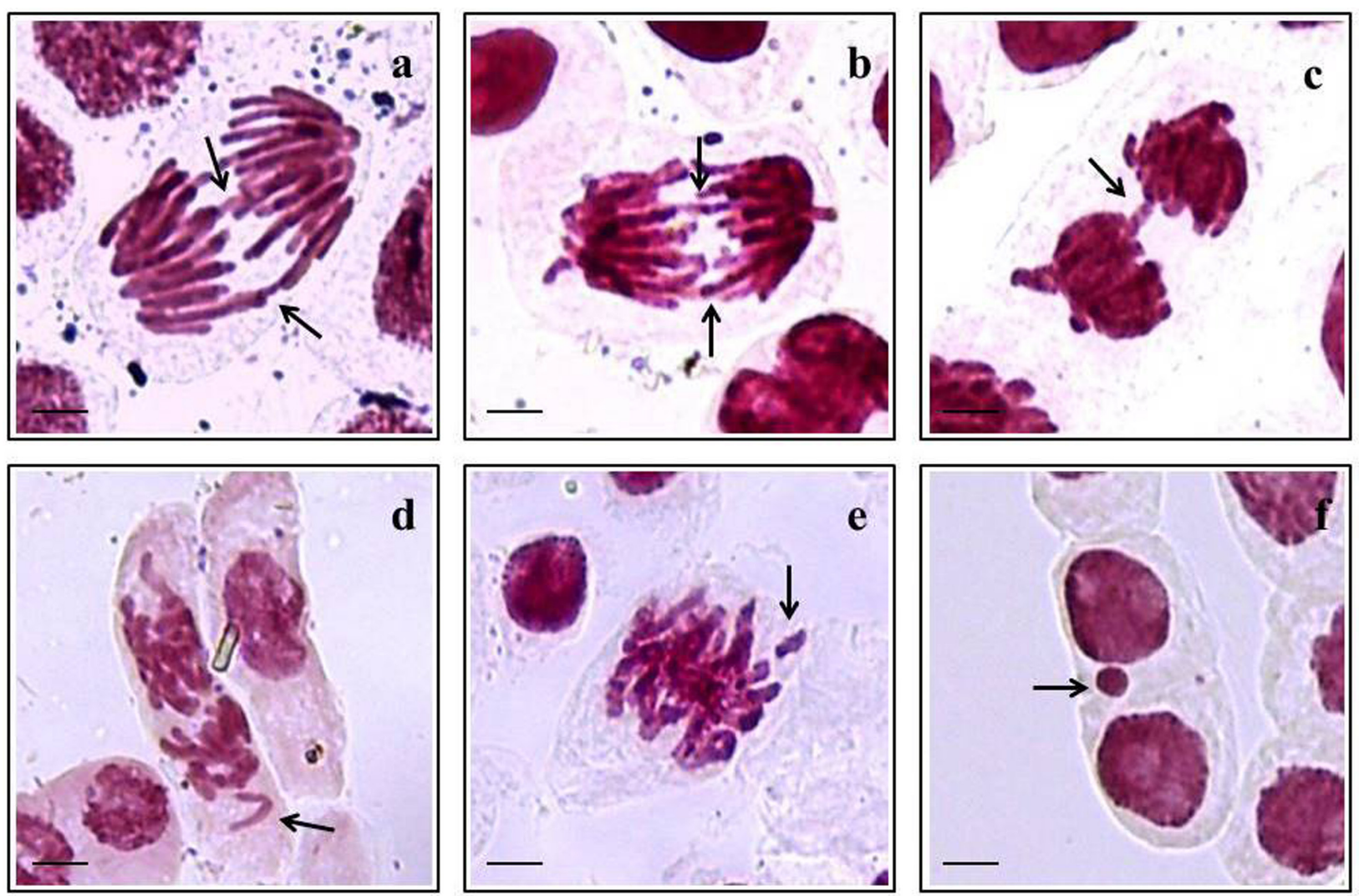

Figure 1 - Allium cepa cells submitted to the aqueous extracts of Sambucus australis. a - arrow indicating anaphasic bridge (cell treated with aqueous extract of inflorescences $0.003 \mathrm{~g} / \mathrm{ml}$, accession 1); $\mathbf{b}$ - arrow indicating anaphasic bridge (cell treated with glyphosate $1 \%$ ); $\mathbf{c}$ - arrow indicating telophase with bridge (cell treated with glyphosate 1\%); $\mathbf{d}$ - arrow indicating laggard chromosomes (cell treated with aqueous extract of inflorescences $0.012 \mathrm{~g} / \mathrm{ml}$, accession 2); $\mathbf{e}-$ arrows indicating breakage (cell treated with glyphosate $1 \%$ ); $\mathbf{f}$ - arrow indicating micronucleus (cell treated with glypho +24 hours leaves at $0.012 \mathrm{~g} / \mathrm{ml}$, accession 2). Scale $=10 \mu \mathrm{m}$.

chromosomal alterations observed in the positive control (T10) and in the negative control (T1) were analyzed and the result of this analysis was compared to the values observed in the T11, T12, T13, T14 and T15 treatments (Table II), where the Allium cepa bulbs were treated for 24 hours with a $1 \%$ glyphosate solution and, subsequently, with distilled water in T11; aqueous extracts from inflorescences of accession 1 at $0.012 \mathrm{~g} / \mathrm{ml}$ in T12; aqueous extracts from leaves of accession 1 at $0.012 \mathrm{~g} / \mathrm{ml}$ in $\mathrm{T} 13$; aqueous extracts from inflorescences of accession 2 at $0.012 \mathrm{~g} / \mathrm{ml}$ in $\mathrm{T} 14$ and aqueous extracts from leaves of accession 2 at $0.012 \mathrm{~g} / \mathrm{ml}$ in T15 for 24 more hours. The T11 was used for the recovery of Allium cepa roots in distilled water, where cells were allowed to undergo division without suffering chromosomal damage caused by the $1 \%$ glyphosate exposure (Peron et al. 2009). Moreover, T11 (17 alterations), T12 (27 alterations), T13 (11 alterations), T14 (21 alterations) and T15 (10 alterations) had significant difference when compared to the negative control (no alterations). The treatments cited above (Table II) also significantly differed from the positive control (50 alterations) while T12 and T14 did not significantly differed from $\mathrm{T} 11$. The results obtained in T13 (a 1\% glyphosate +24 hours in aqueous extract from leaves at $0.012 \mathrm{~g} / \mathrm{ml}-$ Accession 1) and in T15: (a 1\% glyphosate +24 hours in aqueous extract from leaves at $0.012 \mathrm{~g} /$ 
$\mathrm{ml}$ - Accession 2) showed a significant reduction in terms of chromosomal alterations with means equal to 2.7 and 2.5 , respectively, in comparison to T10 (a 1\% glyphosate for positive control) and T11 (a $1 \%$ glyphosate +24 hours in water) with means equal to 12.5 and 4.25 , respectively, indicating that the aqueous extracts from leaves of both accessions of Sambucus australis at $0.012 \mathrm{~g} / \mathrm{ml}$ concentration have antigenotoxic potential on the Allium cepa cell cycle.

In a study developed by Sturbelle et al. (2010), Aloe vera (L.) Burm. f. solutions were tested using the Allium cepa test to determine the level of antimutagenicity of this plant. In this experiment, Allium cepa roots remained for 24 hours in a solution containing $800 \mathrm{mg} / 1$ paracetamol in order to induce chromosomal mutations. As a result, Aloe vera solutions performed similarly to the Sambucus australis leaf extracts analyzed in the present study. Aloe vera solutions evinced antimutagenic activity when followed by a 24-hour exposure to paracetamol.

In another study, Kuhn et al. (2015) evaluated the antimutagenic activity of aqueous extracts of Eugenia uniflora L. (Surinam cherry) and; in this study, the authors also observed that E. uniflora extracts at highest concentration $(24 \mathrm{~g} / \mathrm{l})$ showed antimutagenic effect.

The tables III and IV show the phenolic compounds that were identified in the extracts from inflorescences and leaves of Sambucus australis at $0.012 \mathrm{~g} / \mathrm{ml}$ through the phytochemical analysis using high-performance liquid chromatography (HPLC-DAD). This analysis allowed us to identify the following compounds: gallic acid, chlorogenic acid, caffeic acid, ellagic acid, rutin, quercitrin, isoquercitrin, quercetin and kaempferol. All compounds were found in the aqueous extracts from inflorescences and leaves of Sambucus australis. By analyzing the extracts from flowers of Sambucus australis, Alice et al. (1990) identified flavonoids classified as dihydroflavonol-3-O- monoglucoside and flavonol-3,7-O-diglucoside, isoquercitrin, rutin and quercetin, as well as caffeic and chlorogenic acids. Besides, through the screening of the Sambucus australis flowers, the authors observed the presence of flavonoids in great amount, and sterols and triterpenes in lower amount. L.B. Pavanelo (unpublished data) in turn analyzed aqueous extracts from the leaves and fruits of Cordia trichotoma (Vell.) Arráb. ex Steud. in order to determine their phytochemical composition. Some of the compounds identified by Pavanello in the species Cordia trichotoma were also indentified in Sambucus australis, for instance, caffeic acid, chlorogenic acid, gallic acid, ellagic acid, kaempferol, isoquercitrin, quercetin, quercitrin and rutin, as well as rosmarinic acid, catechin and epicatechin.

The investigation carried out using HLPC chromatographic profiles showed that kaempferol (major compound) as well as chlorogenic and ellagic acids were found in higher quantity in the aqueous extracts from the inflorescences of Sambucus australis (Figure 2). On the other hand, chlorogenic acid (major compound) as well as caffeic and ellagic acids were the predominant compounds in the aqueous extracts from the leaves of Sambucus australis (Figure 2). The major pharmacologic activity attributed to these compounds is the antioxidant effect (Bianchi and Antunes 1999, Soares 2002, Dornas et al. 2007), since they act as free radical kidnappers (Shahidi et al. 1992).

The phytochemical analysis showed a significant difference among the means of accessions 1 and 2 in the majority of the analyzed phenolic compounds. However, when accession 1 was compared to accession 2, there was no significant difference in the levels of mitotic index in the Allium cepa cells that were submitted to the aqueous extracts from inflorescences and leaves of Sambucus australis (Table I). Despite the difference of altitude of the places where the accessions were 
TABLE III

Phenolic compounds ( $\mathrm{mg} / \mathrm{g}$ ) of aqueous extracts of the inflorescences of Sambucus australis in the concentration of $0.012 \mathrm{~g} /$ $\mathrm{ml}$ in Santa Maria, RS (accession 1) and Erechim, RS (accession 2). CV\% $=0.68$.

\begin{tabular}{|c|c|c|c|c|}
\hline Compounds/infloresc. & Accession 1 & Accession 2 & $\operatorname{LOD}^{\#}\left(\mu \mathrm{g} \cdot \mathrm{mL}^{-1}\right)$ & $\mathrm{LOQ}^{\#}\left(\mu \mathrm{g} \cdot \mathrm{mL}^{-1}\right)$ \\
\hline Gallic acid & $7.6100^{\mathrm{fA}^{*}}$ & $5.5067^{\mathrm{fB}}$ & 0.023 & 0.075 \\
\hline Chlorogenic acid & $18.3867^{\mathrm{bA}}$ & $12.0900^{\mathrm{cB}}$ & 0.008 & 0.026 \\
\hline Caffeic acid & $7.4933^{\mathrm{fA}}$ & $5.5233^{\mathrm{fB}}$ & 0.015 & 0.049 \\
\hline Ellagic acid & $12.0800^{\mathrm{cB}}$ & $14.6500^{\mathrm{bA}}$ & 0.027 & 0.093 \\
\hline Rutin & $8.563^{\mathrm{eB}}$ & $10.2433^{\mathrm{dA}}$ & 0.019 & 0.062 \\
\hline Quercitrin & $5.3967^{\mathrm{gA}}$ & $2.313^{\mathrm{gB}}$ & 0.013 & 0.042 \\
\hline Quercetin & $2.2800^{\mathrm{hA}}$ & $2.3033^{\mathrm{gA}}$ & 0.024 & 0.079 \\
\hline Isoquercitrin & $11.7400^{\mathrm{dA}}$ & $6.6800^{\mathrm{eB}}$ & 0.017 & 0.056 \\
\hline Kaempferol & $20.9600^{\mathrm{aA}}$ & $20.2300^{\mathrm{aB}}$ & 0.035 & 0.115 \\
\hline
\end{tabular}

*Means with the same small letter in the column or capital letter on the line do not differ by the Scott-Knott test at 5\% probability. \#LOD: limit of detection; LOQ: limit of quantification.

TABLE IV

Phenolic compounds (mg/g) of aqueous extracts of the leaves of Sambucus australis in the concentration of $0.012 \mathrm{~g} / \mathrm{ml}$ in Santa Maria, RS (accession 1) and Erechim, RS (accession 2). CV\%=0.40.

\begin{tabular}{|c|c|c|c|c|}
\hline Compounds/leaves & Accession 1 & Accession 2 & $\mathrm{LOD}^{\#}\left(\mu \mathrm{g} \cdot \mathrm{mL}^{-1}\right)$ & $\operatorname{LOQ}^{\#}\left(\mu \mathrm{g} \cdot \mathrm{mL}^{-1}\right)$ \\
\hline Gallic acid & $5.6700^{\mathrm{gB} *}$ & $7.7700^{\mathrm{eA}}$ & 0.023 & 0.075 \\
\hline Chlorogenic acid & $18.7500^{\mathrm{aA}}$ & $17.0900^{\mathrm{aB}}$ & 0.008 & 0.026 \\
\hline Caffeic acid & $9.7533^{\mathrm{cA}}$ & $9.6433^{\mathrm{dB}}$ & 0.015 & 0.049 \\
\hline Ellagic acid & $8.0200^{\mathrm{eB}}$ & $10.1800^{\mathrm{cA}}$ & 0.027 & 0.093 \\
\hline Rutin & $5.8200^{\mathrm{fB}}$ & $11.7133^{\mathrm{bA}}$ & 0.019 & 0.062 \\
\hline Quercitrin & $7.9267^{\mathrm{eA}}$ & $3.2633^{\mathrm{hB}}$ & 0.013 & 0.042 \\
\hline Quercetin & $4.0667^{\mathrm{hB}}$ & $5.9433^{\mathrm{gA}}$ & 0.024 & 0.079 \\
\hline Isoquercitrin & $11.4467^{\mathrm{bA}}$ & $1.4500^{\mathrm{iB}}$ & 0.017 & 0.056 \\
\hline Kaempferol & $8.1233^{\mathrm{dA}}$ & $7.2900^{\mathrm{fB}}$ & 0.035 & 0.115 \\
\hline
\end{tabular}

*Means with the same small letter in the column or capital letter on the line do not differ by the Scott-Knott test at 5\% probability. \#LOD: limit of detection; LOQ: limit of quantification.

collected, a positive correlation between the total content of flavonoids and the altitude (Gobbo-Neto and Lopes 2007), and also the variance in terms of the amount of the compounds when the accessions were compared, the phenolic compounds did not influence the inhibition of cell division. Thus, the antiproliferative activity caused by the aqueous extracts of Sambucus australis may be the result of the interaction of the phenolic compounds (synergism), instead of the action of one or some compounds specifically (Martins et al. 2000).
Cechinel Filho and Yunes (1998) demonstrated that different extracts of Phyllanthus sellowianus (Klotzsch) Müll. Arg. caused strong analgesic effects in experimental pain models conducted in rats. As the authors demonstrated, several active compounds were isolated and tested positively with regard to their analgesic effect which may also be the result of synergism among the compounds just as in the present study.

The experiment conducted in the present study allowed us to verify that the aqueous extracts from 


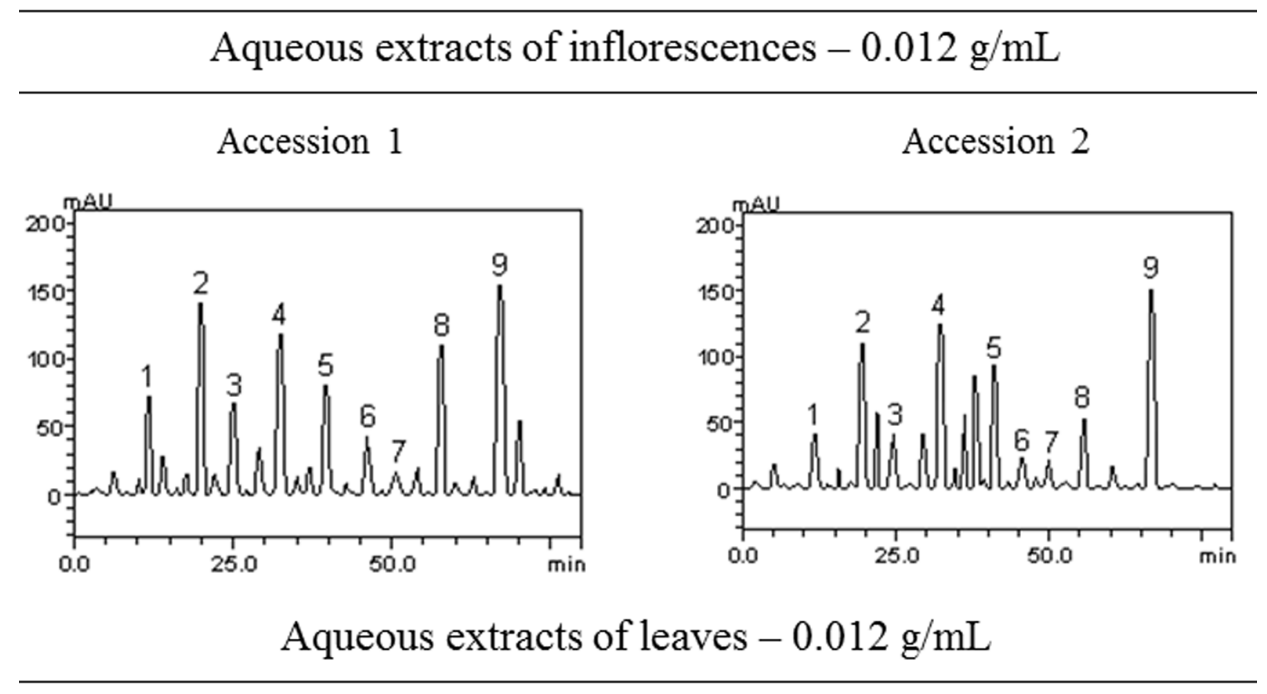

Accession 1

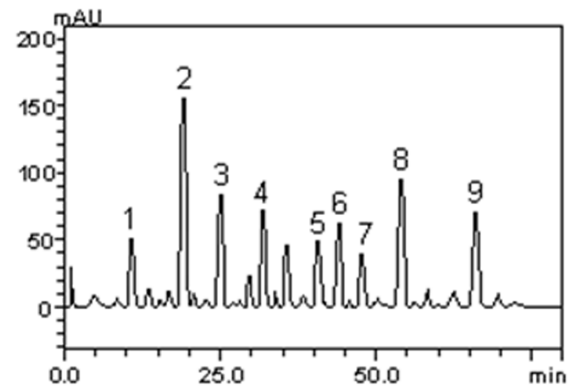

Accession 2

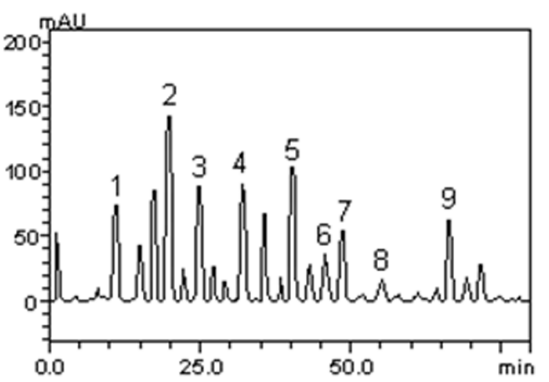

Figure 2 - Representative high performance liquid chromatography profile of Sambucus australis inflorescences (accession 1 and accession 2) and leaves (accession 1 and accession 2). Gallic acid (peak 1), chlorogenic acid (peak 2), caffeic acid (peak 3), ellagic acid (peak 4), rutin (peak 5), quercitrin (peak 6), isoquercitrin (peak 7), quercetin (peak 8) and kaempferol (peak 9).

the inflorescences and leaves of the two accessions of Sambucus australis have antiproliferative and non-genotoxic potential upon Allium cepa cells. Besides, the aqueous extracts prepared from the leaves of both accessions of Sambucus australis at a $0.012 \mathrm{~g} / \mathrm{ml}$ concentration demonstrated antigenotoxic activity, reducing the damage caused by the glyphosate. Moreover, the phytochemical analysis of the extracts using high-performance liquid chromatography made it possible to determine the following phenolic compounds: gallic acid, chlorogenic acid, caffeic acid, ellagic acid, rutin, quercitrin, isoquercitrin, quercetin and kaempferol, of which kaempferol and chrologenic acid were the most predominant compounds in the extracts from inflorescences and leaves, respectively.

\section{ACKNOWLEDGMENTS}

To the teacher Thais Scotti Canto-Dorow for species identification, Conselho Nacional de Desenvolvimento Científico e Tecnológico (CNPq), Coordenação de Aperfeiçoamento de Pessoal de Nível Superior (CAPES) and Fundação de Amparo à Pesquisa do Estado do Rio Grande do Sul (FAPERGS/CAPES) for financial support. 


\section{REFERENCES}

ALAERTS G, MATTHIJS N, VERBEKE J AND HEYDEN Y. 2007. Chromatographic fingerprint development for herbal extract: A screening and optimization methodology on monolithic columns. J Chromatogr A 1172(1): 1-8.

ALICE CB, SIQUEIRA NCS, HALBIG JC, MENTZ LA, SILVA GAAB AND GOETTEMS EI. 1990. Diagnose comparativa de compostos polifenólicos de Sambucus nigra L. e Sambucus australis Cham. \& Schlecht. Rev Bras Farm 71(4): 88-90.

ANVISA - AGÊNCIA NACIONAL DE VIGILÂNCIA SANITÁRIA. 2010. Resolução. Dispõe sobre a notificação de drogas vegetais junto à Agência Nacional de Vigilância Sanitária (ANVISA) e dá outras providências. Diário Oficial da União, Brasília, DF, Seção 1, p. 52-59.

BACIGALUPO NM. 1974. Caprifoliaceae. In: Burkart A. Flora Ilustrada de Entre Rios (Argentina), v.6, Buenos Aires: INTA, p. 50-52.

BAGATINI MD, FACHINETTO JM, SILVA ACF AND TEDESCO SB. 2009. Cytotoxic effects of infusions (tea) of Solidago microglossa DC. (Asteraceae) on the cell cycle of Allium cepa. Rev Bras Farmacogn 19: 632-636.

BAGATINI MD, SILVA ACF AND TEDESCO SB. 2007. Uso do sistema teste de Allium cepa como bioindicador de genotoxicidade de infusões de plantas medicinais. Rev Bras Farmacogn 17: 444-447.

BIANCHI MLP AND ANTUNES LMG. 1999. Radicais livres e os principais antioxidantes da dieta. Rev Nutr 12(2): 123130.

BOLIGON AA ET AL. 2013. Antimicrobial and antiviral activity-guided fractionation from Scutia buxifolia Reissek extracts. Acta Physiol Plant 35: 2229-2239.

CAMPAROTO ML, TEIXEIRA RO, MANTOVANI MS AND VICENTINI VEP. 2002. Effects of Maytenus ilicifolia Mart. and Bauhinia candicans Benth infusions on onion root-tip and rat bone-marrow cells. Genet Mol Biol 25: $85-89$.

CECHINEL FILHO V AND YUNES RA. 1998. Estratégias para a obtenção de compostos farmacologicamente ativos a partir de plantas medicinais, conceitos sobre modificação estrutural para a otimização da atividade. Quim Nova 21: 99-105.

CORDELL JL. 1995. A guide to developing clinical pathways. MLO Med Lab 27(4): 35-39.

CRUZ GL. 1979. Dicionário das Plantas Úteis do Brasil. Rio de Janeiro: Civilização Brasileira, 599 p.

DIAS MG, CANTO-DOROW TS, COELHO APD AND TEDESCO SB. 2014. Efeito genotóxico e antiproliferativo de Mikania cordifolia (L.F.) Willd. (Asteraceae) sobre o ciclo celular de Allium cepa L. Rev Bras Plantas Med 16(2): 202-208.
DORNAS WC, OLIVEIRA TT, RODRIGUES-DAS-DORES RG, SANTOS AF AND NAGEM TJ. 2007. Flavonoides: potencial terapêutico no estresse oxidativo. Rev Ciênc Farm Básica Apl 28: 241-249.

FACHINETTO JM, BAGATINI MD, DURIGON J, SILVA ACF AND TEDESCO SB. 2007. Efeito antiproliferativo das infusões de Achyrocline satureioides DC (Asteraceae) sobre o ciclo celular de Allium cepa. Rev Bras Farmacogn 17: 49-54.

FACHINETTO JM AND TEDESCO SB. 2009. Atividade antiproliferativa e mutagênica dos extratos aquosos de Baccharis trimera (Less.) A. P. de Candolle e Baccharis articulata (Lam.) Pers. (Asteraceae) sobre o sistema teste de Allium cepa. Rev Bras Plan Med 11: 360-367.

FIRBAS P AND AMON T. 2014. Chromosome damage studies in the onion plant Allium cepa L. Caryologia 67(1): 25-35.

FISKESJÖ G. 1985. The Allium test as a standard in environmental monitoring. Hereditas 102(1): 99-112.

FRESCURA VD, LAUGHINGHOUSE IV AND TEDESCO SB. 2012. Antiproliferative effect of the tree and medicinal species Luehea divaricata on the Allium cepa cell cycle. Caryologia 65: 27-33.

GOBBO-NETO L AND LOPES NP. 2007. Plantas medicinais: fatores de influência no conteúdo de metabólitos secundários. Quim Nova 30(2): 374-381.

GUARRERA PM, FORTI G AND MARIGNOLI S. 2005. Ethnobotanical and ethnomedicinal uses of plants in the district of Acquapendente (Latium, Central Italy). J Ethnopharmacol 96: 429-444.

GUERRA M AND SOUZA MJ. 2002. Como observar os cromossomos: um guia de técnicas em citogenética vegetal, animal e humana. Ribeirão Preto: FUNPEC.

HAMBURGER M AND HOSTETTMANN K. 1991. Bioactivity in Plants: the Link Between Phytochemistry and Medicine. Phytochemistry 30(12): 3864-3874.

HOLLMAN PCH, VAN TRIP JMP AND BUYSMAN MNCP. 1996. Fluorescence detection of flavonols in HPLC by post-column chelation with aluminium. Anal Chem 68: 3511-3515.

JORGE LIF, GRACIANO RAS, PRADO SPT AND PEREIRA U. 1999. Identificaçäo histológica de Sambucus australis Cham. \& Schlecht. (Sabugueiro). Rev Ciên Farm 20: 117123.

KABARITY A AND MALALLAH G. 1980. Mitodepressive effect of Khat (Catha edulis) in the meristematic region of Allium cepa root tips. Cytologia 45: 733-738.

KAMDEM JP, OLALEKAN EO, HASSAN W, KADE J, YETUNDE O, BOLIGON AA, ATHAYDE ML, SOUZA DO AND ROCHA JBT. 2013. Trichilia catigua (Catuaba) bark extract exerts neuroprotection againstoxidative stress induced by different neurotoxic agents in rathippocampal slices. Ind Crop Prod 50: 625- 632. 
KNOLL MF, SILVA ACF, CANTO-DOROW TS AND TEDESCO SB. 2006. Effects of Pterocaulon polystachyum DC. (Asteraceae) on onion (Allium cepa) root-tip cells. Genet Mol Biol 29: 539-542.

KÖPPEN W. 1948. Climatologia: con un estudio de los climas de la tierra. México: Fondo de Cultura Econômica, 479 p.

KUHN AW, TEDESCO M, LAUGHINGHOUSE IV HD, FLORES FC, SILVA CB, CANTO-DOROW TS AND TEDESCO SB. 2015. Mutagenic and antimutagenic effects of Eugenia uniflora L. by the Allium cepa L. test. Caryologia 68: 25-30.

KUTCHAN TM. 2001. Ecological arsenal and developmental dispatcher. The paradigm of secondary metabolism. Plant Physiol 125: 58-60.

LEME DM AND MARIN-MORALES MA. 2008. Chromosome aberration and micronucleus frequencies in Allium cepa cells exposed to petroleum polluted water - a case study. Mutat Res 650: 80-86.

LORENZI H AND MATOS FJA. 2008. Plantas medicinais no Brasil: nativas e exóticas. $2^{\text {a }}$ ed., Nova Odessa: Plantarum, $544 \mathrm{p}$.

MARTINS ER, CASTRO DM, CASTELLANI DC AND DIAS JE. 2000. Plantas Medicinais. Viçosa: UFV, 220 p.

MODALLAL N, ABDERRAHMAN SM AND PAPINI A. 2008. Cytogenetic Effect of Arum maculatum Extract on the Bone Marrow Cells of Mice. Caryologia 61(4): 383-387.

NORA GD, PASTORI T, LAUGHINHOUSE IV HD, CANTODOROW TS AND TEDESCO SB. 2010. Antiproliferative and genotoxic effects of Mikania glomerata (Asteraceae). Biocell 34: 95-101.

PELZER L, GUARDIA T, JUAREZ A AND GUERREIRO E. 1998. Acute and chronic Acute and chronic antiinflammatory effects of plant flavonoids. Il Farmaco 53: 421-424.

PERON AP, CANESIN EA AND CARDOSO CMV. 2009. Potencial mutagênico das águas do Rio Pirapó (Apucarana, Paraná, Brasil) em células meristemáticas de raiz de Allium cepa L. R Bras Bioci 7(2): 155-159.

PINHO DS, STURBELLE RT, MARTINHO-ROTH MG AND GARCIAS GL. 2010. Avaliação da atividade mutagênica da infusão de Baccharis trimera (Less.) DC. em teste de Allium cepa e teste de aberrações cromossômicas em linfócitos humanos. Rev Bras Farmacogn 20: 65-170.
REITZ R. 1985. Caprifoliáceas. In: Flora Ilustrada Catarinense. Itajaí. Fasc, 16 p.

SHAHIDI F, JANITHA PK AND WANASUNDARA PD. 1992. Phenolic antioxidants. Crit Rev Food Sci Nutr 32(1): 67-103.

SILVA CR, MONTEIRO MR, CALDEIRA-DE-ARAÚJO A AND BEZERRA RJAC. 2004. Absence of mutagenic and citotoxic potentiality of senna (Cassia angustifolia Vahl.) evaluated by microbiological tests. Rev Bras Farmacogn 14: 1-3.

SILVA FAS AND AZEVEDO CAV DE. 2009. Principal components analysis in the software assistat-statistical attendance. In: World congress on computers in agriculture, 7, Reno-NV-USA: American Society of Agricultural and Biological Engineers.

SOARES SE. 2002. Ácidos fenólicos como antioxidantes. Rev Nutr 15(1): 71-81.

SOUZA LFB, LAUGHINGHOUSE IV HD, PASTORI T, TEDESCO M, KUHN AW, CANTO-DOROW TS AND TEDESCO SB. 2010. Genotoxic potential of aqueous extracts of Artemisia verlotorum on the cell cycle of Allium cepa. Int J Environ Stud 67: 871-877.

STURBELLE RT, PINHO DS, RESTANI RG, OLIVEIRA GR, GARCIAS GL AND MARTINO-ROTH MG. 2010. Avaliação da atividade mutagênica e antimutagênica da Aloe vera em teste de Allium cepa e teste de micronúcleo em linfócitos humanos binucleados. Rev Bras Farmacogn 20(3): 409-415.

TAIZ L AND ZEIGER E. 2013. Fisiologia Vegetal. 5a ed., Porto Alegre: Artmed, $918 \mathrm{p}$.

TEDESCO SB AND LAUGHINGHOUSE IV HD. 2012. Bioindicator of Genotoxicity: The Allium cepa Test. In: Environmental Contamination. Rijeka: Intech Publisher, p. 137-156.

TEIXEIRA RO, CAMPAROTO ML, MANTOVANI MS AND VICENTINI VEP. 2003. Assessment of two medicinal plants, Psidium guajava L. and Achillea millefolium L., in in vitro and in vivo assays. Genet Mol Biol 26(4): 551-555.

ZUANAZZI JAS. 2001. Flavonoides. In: Simões CMO, Schenkel EP, Gosmann G, Mello JCP, Mentz LA and Petrovick PR. Farmacognosia: da planta ao medicamento. $3^{\mathrm{a}}$ ed., rev. Porto Alegre: Ed. Universidade/UFRGS; Florianópolis: Ed. da UFSC, 833 p. 